\title{
Land Use Change and Urban Ecosystem Services: A Case Study of Urban Wetlands in a Rapidly Sprawling City in the Highlands of Chiapas, Mexico
}

\author{
Vera Camacho-Valdez ${ }^{1}$, Eva M. Tello-Alcaide ${ }^{2}$, Allen Wootton ${ }^{3} \&$ Emmanuel Valencia-Barrera ${ }^{3}$ \\ ${ }^{1}$ CONACYT-El Colegio de la Frontera Sur (ECOSUR), Periférico Sur s/n, Colonia María Auxiliadora, San \\ Cristóbal de las Casas, Chiapas, México \\ ${ }^{2}$ External consultant, Ranulfo Tovilla 57, Colonia San Nicolás, San Cristóbal de las Casas, Chiapas, México \\ ${ }^{3}$ El Colegio de la Frontera Sur (ECOSUR), San Cristóbal de las Casas, Chiapas, México \\ Correspondence: Vera Camacho-Valdez, Periférico Sur s/n, Colonia María Auxiliadora, San Cristóbal de las \\ Casas, Chiapas, México. E-mail: vcamacho@ecosur.mx
}

Received: January 17, 2019 Accepted: March 15, 2019 Online Published: March 19, 2019

doi:10.5539/jms.v9n1p67 URL: https://doi.org/10.5539/jms.v9n1p67

\begin{abstract}
Urban wetlands provide a wide range of ecosystem services that are important for human-well-being. Despite their social and environmental importance, the degradation of urban wetlands continues mainly due to land use changes induced by rapid urbanization. Estimating the impact of these changes on ecosystem services is crucial to support the decision-making process of city planners at different levels. In this study, the spatial extents of the urban wetlands of San Cristobal de Las Casas, Chiapas, Mexico were determined for the years 2001 and 2018 in order to relate the spatial changes between these years with the provision and economic value of ecosystem services. Google Earth and SPOT imagery were used to evaluate land use/land cover changes while international coefficients were used to assess the value of the ecosystem services by category. Findings reveal a $7.3 \%$ decrease in the urban wetland area and a $12.5 \%$ increase of urban areas during the study period. The ecosystem service valuation shows that the total value flow decreased around \$5 million (2007 USD) during the 17-year period, mainly due to decreases in the potential for regulating and cultural services. The use of freely available land use/land cover data together with global ecosystem service estimates reduce the cost of ground data collection and provides quick and reliable information that could help decision makers with land use planning in the context of data-scarce regions.
\end{abstract}

Keywords: urban wetlands, ecosystem services, land use change, freely available data

\section{Introduction}

In 2016, an estimated 54.5 per cent of the world's population lived in urban settlements. By 2030, urban areas are projected to house 60 per cent of people globally and one in every three people will live in cities with at least half a million inhabitants (United Nations, 2016). Although developing countries started the process of urbanization more recently, they are now experiencing a higher level of urbanization than in developed countries (Montgomery, 2008). This rapid urbanization implies massive investment in urban infrastructure and profound changes in urban ecosystems and landscapes (Green et al., 2016) that has many negative environmental effects, and subsequently effects in the benefits people obtain directly or indirectly from ecosystems, known as "ecosystem services" (ES) (Costanza et al., 1997; MEA, 2005). The environmental dimension impacts include the loss of biodiversity (Grimm et al., 2008; Atu et al., 2013), air and water pollution (Wilson et al., 2003), noise (Derkzen et al., 2015), higher GHG emissions (Glaeser \& Kahn, 2004) and increasing runoff and flood potential (Poelmans et al., 2009). These impacts are particularly important in developing countries where there is limited capacity to cope with the environmental and social consequences of rapid urban expansion (Cohen, 2006). This unprecedented urbanization emphasizes the need for innovative approaches to generating knowledge before, during and after the process of urbanization in an adaptive mode (Ahern et al., 2014).

\subsection{Valuation of Urban Wetland Ecosystem Services}

In recent years, the study of urban ecosystem services (UES) is emerging as an important research frontier for 
the incorporation of the benefits of ecosystems for urban health and well-being (Gómez-Baggethun \& Barton, 2013; Kremer et al., 2016; Derkzen et al., 2015), security (Whitford et al., 2001), economy (TEEB, 2011), and as a tool for improving urban sustainability (Elmqvist et al., 2013) and resilience (McPhearson et al., 2013). Urban ecosystems provide vital ecosystem services for urban dwellers (McDonald \& Marcotullio, 2011) and these UES are generated by a diverse set of land use/land covers (LULC), comprising of wetlands, parks, golf courses, gardens and yards, sports fields, among others (Haase et al., 2014). Urban wetlands are considered one of the most important ecosystems in urban areas because they provide a variety of valuable ecosystem services, including water purification, filtration, retention of nutrients, flood control, ground-water recharge, and providing habitat for a variety of species. Wetlands are also valued for recreational and aesthetic reasons (Boyer \& Polasky, 2004). Despite their social importance in the support of human well-being, the degradation and loss of wetlands continues. Urbanization has become a major cause of the loss of wetland area. Wetland destruction in urban areas occurs mainly due to the conversion of LULC to commercial and residential development and establishment of road infrastructure (Azous \& Horner, 2000), thereby resulting in negative impacts on biodiversity as well as in the alteration of functional processes, thus diminishing the provision of ecosystem services to local society.

The estimation of a monetary value for wetland ecosystem services is increasingly recognized as a valuable tool that facilitates better social decision-making in wetland protection versus land-use development conflict situations, and represents a foundation for the rational and sustainable utilization of environmental resources (Mitsch \& Gosselink, 2000; Boyer \& Polasky, 2004; Barbier, 2007; Turner et al., 2008; Gómez-Baggethun \& Barton, 2013). In this sense, notable studies have estimated the changes in ecosystem service values (ESV) provided by wetlands in response to land use changes during urbanization (Kreuter et al., 2001; Zhao et al., 2004; Tong et al., 2007; Li et al., 2010; Su et al., 2012; Haase et al., 2014; Yirsaw et al., 2016; Chuai et al., 2016). In these studies, Geographical Information Systems (GIS) and remote sensing techniques have been used to examine the impacts of LULC changes in ESV identify the points of intervention and direct growth away from sensitive ecological areas (Mosammam et al., 2016). Recent advances in remote-sensing data with improved spatial accuracy and availability of free to less expensive satellite images coupled with GIS allow quantitative analyses of the rate and pattern of LULC with reasonable cost and better accuracy (Haack \& Rafter, 2006). The results of these studies provide useful information to land managers and policy makers because they can recognize the relationships among urban ecosystems and the services which they provide to local inhabitants.

\subsection{Study Site Context}

Previous research on urban ecosystems, including urban wetlands, has focused on cities in North America, Europe and Asia (Beninde et al., 2015), which are among the most highly urbanized continents (United Nations, 2016). In contrast, there is a lack of urban and wetland ecosystem services research in less urbanized and less economically developed regions (Luederitz et al., 2015). It is increasingly recognized that ecosystem services must be incorporated into urban planning (Colding, 2011). Therefore, effective governance and planning to achieve a more sustainable urban form are crucial and one of the major challenges for urban planners and policy makers in these countries.

Mexico is considered a country with a considerable urban growth. The urban population has been increasing steadily and has gone from 47.9 million in 1990 to 81.2 million in 2010 and is projected to have an additional increase of 13.1 million by 2030 (INEGI, 2010a). This urbanization process is being carried out in accordance with a model of disconnected land occupation characterized by a fragmented expansion of the urban area (Libertun \& Guerrero, 2017) which has generated enormous pressure on natural resources.

The city of San Cristobal de Las Casas (SCC), located in southeastern Mexico and selected as our case study, has experienced a rapid urbanization especially over the past few decades following the rise of tourism activity, with an annual growth rate of 6.3\% (INEGI, 2010b; Figueroa-Jáuregui et al., 2011; Figure 1). The concentration of the population and the need for housing, together with the lack of municipal regulation and economic interests has caused the degradation of important urban wetlands (Calderon-Cisneros et al., 2012). In fact, urbanization has been reported as the most influential anthropic impact on the reduction of these wetlands (Merino, 2013). In general, fragmentation of wetlands due to increases in urban encroachment and road development alter and hinder the movement of water and migration of plants and animals in these areas (Boyer \& Polasky, 2004). Overall, this situation has had a direct impact on the capacity of urban wetlands to provide ecosystem services to local people; for example, the capacity of recharging the aquifer is reduced, causing water scarcity, particularly in the periphery neighborhoods, which are the most marginalized areas of the city (Cruz-Morales \& Hernández-Pérez, 2010). Therefore, in order to reverse this situation and enhance local decision-making processes, it is necessary to generate information about the links between urbanization and the consequent 
impact on the provision of a range of ecosystem services provided by wetlands (Boyer \& Polasky, 2004).

Although in Mexico, studies on the measurement of wetland ecosystem service value variations as a consequence of land use changes have been carried out, most of them have focused on coastal wetlands (Mendoza-González et al., 2012; Camacho-Valdez et al., 2014) or some ecosystem services derived from them (Perez-Verdin et al., 2016). The main finding of these studies has been the significant loss of the ecosystem service values in mangroves ecosystems mainly caused by an increase in urban areas. On the other hand, for urban wetlands few studies have been performed and most of them have carried out in big cities (Jujnovsky et al., 2012; Merlin-Uribe et al., 2013), even when these ecosystems are considered as one of the most valuable ecosystems because they supply a number of ecosystem services in cities (Ibarra et al., 2013). In fact, according to Chaikumbung et al. (2016) urban wetlands are more valuable than other wetlands (e.g., rural wetlands).

In our case study, few studies published as journal articles have been directly related to the local urban wetlands even when urban developments have increased in the city, worsening the degradation and loss of natural ecosystems (Calderon-Cisneros et al., 2012). In one example, a report by Pronatura Sur A.C., an environmental non-governmental organization (ENGO), showed maps of the location and level of degradation of urban wetlands in San Cristobal from 2006 to 2011 (Rojas \& Alba, 2011). Other studies relevant to this area have included descriptions of the conservation situation of an endemic species of fish, the San Cristobal pupfish (Profundulus hildebrandi) (Velázquez-Velázquez \& Schmitter Soto, 2004; Velázquez-Velázquez et al., 2009), land use implications for agricultural areas within San Cristobal (Vásquez-Moreno \& Córdova, 2013, Nahed-Toral et al., 2011), flood risks in the city (Gómez et al., 2008) and land use changes and carbon flux of the highland region forests of Chiapas (De Jong et al., 1999). In this sense, it is necessary to analyze the particular dynamic of LULC and their effect on wetland ecosystems services in a medium size city, since these cities will be where the greatest urban growth will be concentrated in the future.

\subsection{Study Objective}

The aims of this paper were to: i) identify potential UES to urban dwellers from wetlands as the most appreciated natural element in cities; ii) calculate urban wetland ecosystem service values based on global references; and iii) characterize LULC changes and the effect on urban wetland ecosystem service values. This study would be helpful for the city planners and policy makers to direct future developments and for environmental management.

\section{Methods}

\subsection{Study Area}

San Cristobal de Las Casas (SCC) is a medium-sized city which has a population of 185,917 inhabitants, counted in the last census of 2010, and since the 1970s has experienced rapid urban sprawl (INEGI, 2010b; Figure 1). Currently, San Cristobal contains $85 \%$ of the municipal population (Figure 2), of which $30 \%$ belongs to indigenous groups of the region (predominantly Tsotsiles) with a high degree of marginalization, as well as numerous inhabitants from other states of the country and abroad (Calderon-Cisneros et al., 2012). The city of San Cristobal is located in Chiapas, Mexico, in a closed or endorheic basin at 2200 meters above sea level, surrounded by forest and mountain wetlands that are a priority for conservation (Arriaga et al., 2000). Overall, the wetlands present in SCC are considered as areas of connection and transition between land and water systems and play a fundamental role in flood control. They are also important reservoirs of groundwater that guarantee the permanent supply of water for the local population, since they influence the supply and protection of 10 springs (Rojas-Garcia \& Alba-Lopez, 2011). These mountain wetlands are considered by the Ramsar Convention as unique and rare. Despite this, their fragility has been accentuated due to urban development, deforestation and agricultural practices that drain and eutrophize the waters (Ramsar Information Sheet, 2007). 


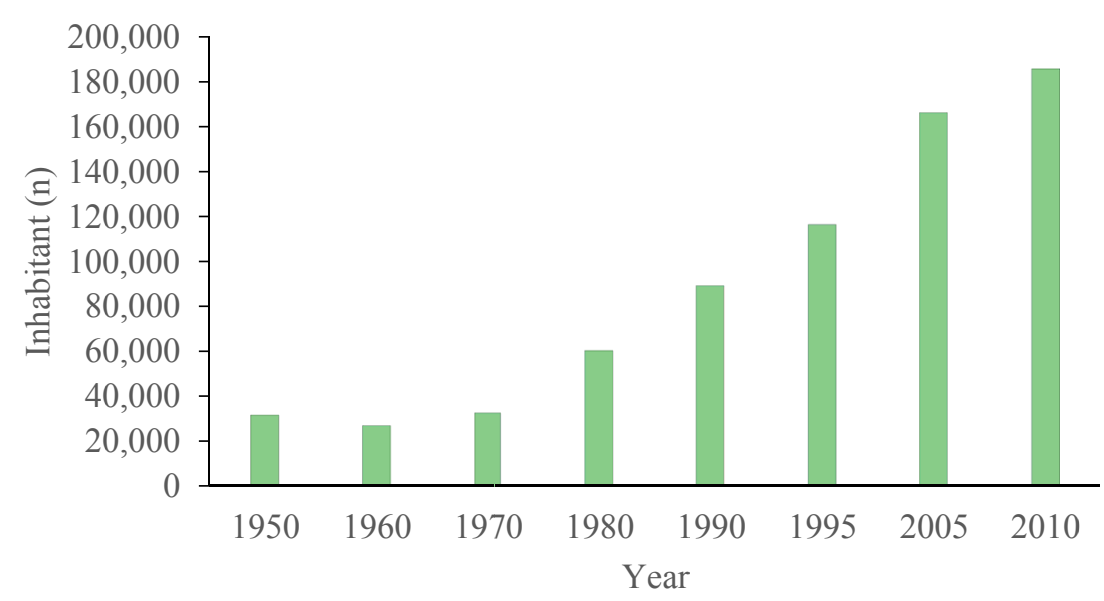

Figure 1. Population profile in San Cristobal de Las Casas city (SCC)

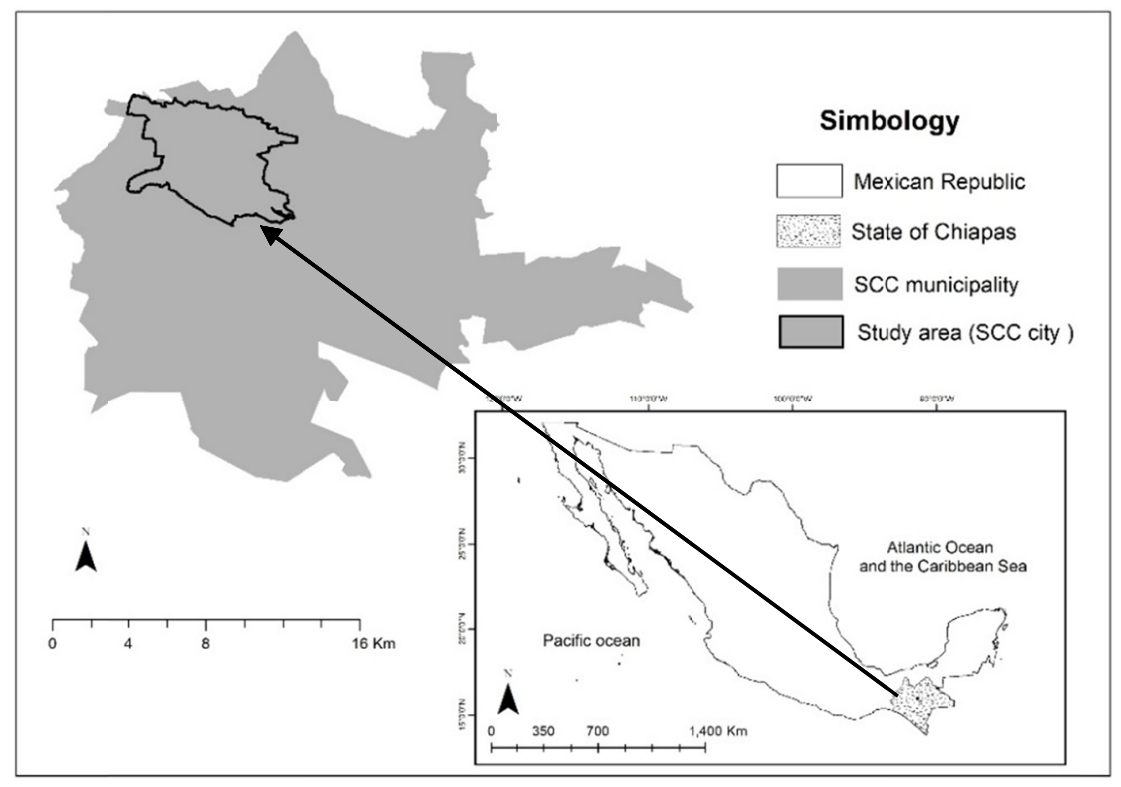

Figure 2. Study area. San Cristobal de Las Casas city (SCC), southern Mexico

The study area is mostly characterized by a warm, subhumid climate with an extensive dry season (from December to April) and $700 \mathrm{~mm}$ rainfall during the summer with an average annual temperature of $15^{\circ} \mathrm{C}$ and an annual mean rainfall of $880 \mathrm{~mm}$ (Bencala et al., 2006).

\subsection{Land Use and Land Cover Analysis}

The data used to identify the spatio-temporal distribution of LULC present in the study area were derived from SPOT 6 and Google Earth images acquired in 2001 and 2018, respectively. SPOT 6 images have four spectral bands and a resolution of 6 meters. Unfortunately, considering the high cost of data acquisition, we were not able to use high-resolution images such as SPOT for the 2018 image analysis. Even though the Landsat Thematic Mapper (TM) images are free and represented a good alternative, the images found for our study area (https://glovis.usgs.gov/) were cloudy and of very low quality to carry out the LULC analysis. Therefore, for 2018 we used Google Earth images as an alternative solution, which provides open, highly spatially resolved images suitable for assessing moderate-resolution remote sensing products across most of the world's urban and peri-urban areas (Guo et al., 2016). The Google Earth image was download at the highest resolution (4800x2701) synchronizing Google Earth Pro (GEP) with ArcMap 10.2.1 through ArcBruTile 0.2.2 tool. The advantage of this tool is that it loads Google Earth satellite images directly into ArcGIS, and offers a good resolution and updated 
images.

Both images (SPOT 6 and Google Earth) were geographically projected to the UTM zone 15 North (WGS84) and limited to the boundaries of the administrative limit of the city of SCC (INEGI, 2014). We work in WGS84 because doing so avoids displacements or deformations that often occur when Arc Map is synchronized with Google Earth in other reference systems. Finally, both images could be compared directly because the coordinate reference system and resolution used in each image was consistent for our purpose.

Thematic layers were digitized in vector format from the images using ArcGis 10.2.1. The use of a -classification processes was ruled out because it would not offer better results than digitization since there was a high level of knowledge by experts about the study area and the boundaries of the land covers included in our study were easily identified (urban settlement, wetlands and other land covers).

The classification of the 2001 SPOT 6 image was digitized using ArcGis 10.2.1 for the categories of settlements, urban wetlands and other land cover. To digitize the urban wetlands, technical documents and a spatial layer that simulates the flood and infiltration zones were used as a basis to define the most relevant water bodies in the study area. For settlements and other land covers, the criteria defined in table 1 were used. The SPOT 62001 image allowed us to digitize vector layers at a scale of 1:2,500. The minimum digitization area was $0.033172 \mathrm{ha} /$ 331.72 square meters. This level of detail was chosen according to the areas where dispersed urbanization existed (e.g., not agglomerated houses).

For the Google Earth 2018 image, settlements areas were digitized following the same criteria as with the 2001 image and using as reference the 2001 settlements layer. To obtain the urban wetlands and other land covers remaining in 2018, an extraction geo-processing was carried out in ArcMap (clip). The layer of settlements 2018 (clip) was subtracted from the layers of urban wetlands and others land covers in 2001. This extraction is supported because in the study period both covers were transformed to urban areas. In addition to the digitalization, a field study was carried out to verify the defined classes of the 2018 land cover analysis.

Table 1. Land-use categories in the study area, together with their definition

\begin{tabular}{ll}
\hline LULC Category & Definition and criteria for digitalization \\
\hline Settlement & $\begin{array}{l}\text { All land used to construct human structures, including residential, commercial and industrial buildings. } \\
\text { Urban wetland }\end{array}$ \\
$\begin{array}{l}\text { Mountain continental wetlands (where there is seasonally saturated), predominant vegetation consists of } \\
\text { grasses and tulares. Include: swamps, marshes and floodplains. }\end{array}$ \\
$\begin{array}{l}\text { Other land cover } \\
\text { land, green urban areas and land under development }\end{array}$ \\
\hline
\end{tabular}

\subsection{Assignment of Ecosystem Service Values}

The ES derived from urban wetlands in San Cristobal were identified based on a review of references from scientific papers, reports, decrees, thesis and Ramsar information sheets, which could provide us with information about the study area. These studies were performed by local NGO's, government agencies, research institutions and universities. Of these, only those documents that gave us specific and reliable information about the ES provided by urban wetlands in San Cristobal were selected. Once we defined the urban ES, we classified them according to TEEB foundations report (2011), which describes 22 ecosystem services and divides them into four main categories: provisioning, regulating, habitat and cultural.

Given the lack of local primary valuation studies, we needed to use international estimations. Therefore, we calculated the value of urban wetland ecosystem services based in the results of the global ecosystem service values obtained by de Groot et al. (2012). We used this new data to produce a more integrative approach that will incorporate a wide range of ecosystem services and thus generate more representative values. We assigned the equivalent coefficient of ESV according to the mean value of inland wetland biome (Table 4). This biome-type included in the de Groot et al. (2012) work was used as a proxy for the urban wetlands occurring in our study area. The inland wetland biome includes: (freshwater) floodplains, swamps/marshes and peat lands. The ecosystem service types found in the reviewed reference documents were standardized with those included in de Groot et al. (2012) for inland biome. To have more reliability in the standardization, the list of all the references (included as Supporting material in de Groot et al., 2012) that had been used for the monetary values by ecosystem service of this biome (inland wetlands) was reviewed. The values of ecosystem services for each year (2001, 2018) were estimated by multiplying the mean values by the area of wetlands for each period. All the monetary values for the analyzed years $(2001,2018)$ were based on 2007 values. 
The change in the value of the ecosystem services was estimated by calculating the differences between the estimated size of wetlands and the ecosystem service values in 2001 and 2018.

\subsection{Spatial Analysis of Ecosystem Service Values}

Flow estimates were then mapped across San Cristobal city showing the losses of the ecosystem service values provided by urban wetlands during the study period (2001-2018). The analysis and map were generated with the GIS software ArcGis 10.2.1 using the previously created LULC transformation map of 2018.

\section{Results}

\subsection{Land Use and Land Cover Changes}

The changes in the area of LULC from 2001 to 2018 is shown in table 2. Overall, the table displays a significant decrease in wetland areas $(-7.4 \%)$ that are related with an increase of the urban land cover $(12.5 \%)$. The cumulative loss of wetlands (260.83 ha) and other land covers $(179.96 \mathrm{ha})$ in this period (2001-2018) is essentially equal to the increase in urban areas (440.80 ha).

Table 2. Land use/land cover dynamics and changes between 2001 and 2018

\begin{tabular}{lllllll}
\hline \multirow{2}{*}{ Land cover category } & 2001 & \multicolumn{3}{c}{2018} & \multicolumn{2}{c}{ Change (2001-2018) } \\
\cline { 2 - 7 } & Area (ha) & $\%$ & Area (ha) & $\%$ & Area (ha) & $\%$ \\
\hline Settlement & $1,490.5$ & 42.1 & $1,931.3$ & 54.6 & 440.8 & 12.5 \\
Urban wetland & 770.3 & 21.8 & 509.5 & 14.4 & -260.8 & -7.4 \\
Other land cover & $1,271.6$ & 36.0 & $1,091.7$ & 30.9 & -179.9 & -5.0 \\
Total & $3,532.5$ & 100 & $3,532.5$ & 100 & & \\
\hline
\end{tabular}

Figure 3 illustrates spatially the development of the LULC changes and highlights the transformation from wetlands to urban settlement in the northwestern zone. The changes of other land cover to settlement is more heterogeneous and are distributed in the whole study area.
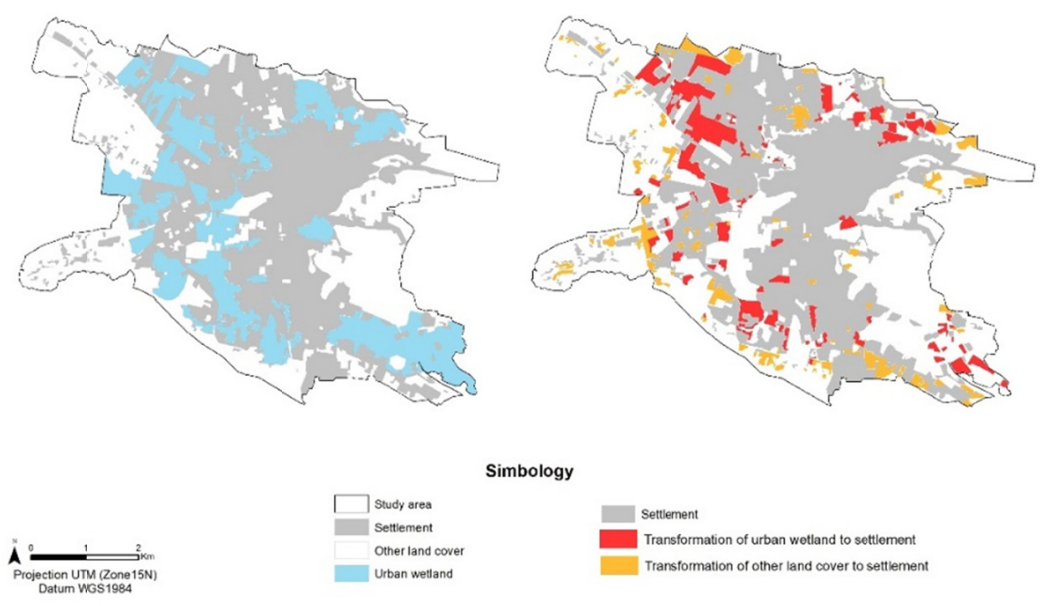

Figure 3. Land use/land cover map of San Cristobal de Las Casas city in 2001 and the transformation of urban wetland and other land cover to settlement in 2018

\subsection{Ecosystem Service Values}

After reviewing regional references, we selected 15 documents (from 45) that mentioned specific information about the ecosystem service types of the SCC urban wetlands (Table 3). In relation to the ES categories, the most representative, in terms of frequency of appearance, were the regulating ES (46.1\%) followed by cultural ES (23.1\%). Less represented were provisioning (17.6\%) and habitat (13.2\%) categories. 
Regarding the highest frequency of appearance by ES type in the total number of documents reviewed, the most important ecosystem service was "collect, store and supply fresh water" with $15 \%$, followed by "flood control and allow water filtration" with $14 \%$, "maintenance of nursery populations and habitats" with $13 \%$ and "climate regulation" with $12 \%$. Overall, cultural ecosystem service types were less important in terms of frequency (Table $3)$.

Table 3. Urban wetland ecosystem services derived from local reviewed documents and the total number of the documents that mention each type of service identified

\begin{tabular}{|c|c|c|c|c|c|c|c|c|c|c|c|c|c|c|c|c|c|}
\hline SE Categories & & & & & & & & & & & & & & & & & \\
\hline $\begin{array}{l}\text { Reviewed } \\
\text { documents }\end{array}$ & 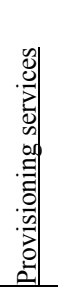 & 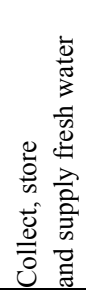 & 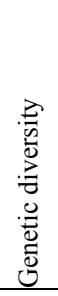 & 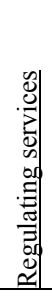 & 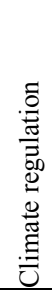 & 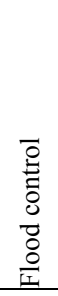 & 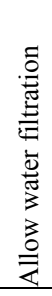 & 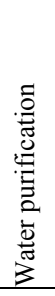 & 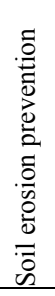 & 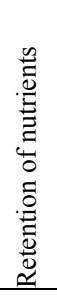 & 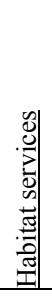 & 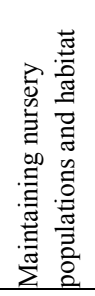 & 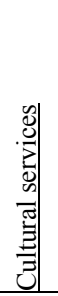 & 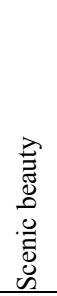 & 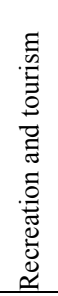 & 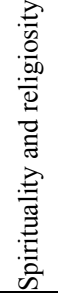 & 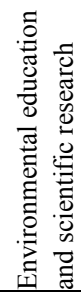 \\
\hline 1. MP of the KMW & & + & + & & + & + & + & & & & & + & & + & + & & + \\
\hline 2. ISRW of KW & & + & & & + & + & + & & & & & + & & + & + & & + \\
\hline 3. KPA Decree & & + & & & + & + & + & & & & & + & & + & & & + \\
\hline 4. CDP & & & & & + & & & & & & & + & & + & + & & \\
\hline 5. SCDLCW: A\&D & & + & & & + & + & + & & & & & & & & & & \\
\hline 6. VJBMP & & + & & & + & + & + & & & & & + & & & & & \\
\hline 7. MP of the KMW & & + & + & & + & + & + & & & & & + & & + & + & & + \\
\hline 8. ISRW of MEW & & + & & & + & + & + & & + & + & & + & & + & + & + & + \\
\hline 9. MECCVJ & & + & & & + & + & + & & & & & + & & & & & \\
\hline 10. VRF in SCDLC & & + & & & & + & + & & & & & & & & & & \\
\hline $\begin{array}{l}\text { 11. JVWSW of } \\
\text { SCDLC }\end{array}$ & & + & & & & + & + & + & & & & + & & & + & + & + \\
\hline $\begin{array}{l}\text { 12. DDMW of } \\
\text { SCDLC }\end{array}$ & & + & & & + & + & + & & + & & & + & & & & + & \\
\hline $\begin{array}{l}\text { 13. NRIMP in } \\
\text { SCDLCB }\end{array}$ & & + & & & & & & & & & & & & & & & \\
\hline $\begin{array}{l}\text { 14. EMPT of } \\
\text { SCDLC }\end{array}$ & & + & & & + & + & + & & & & & + & & & & & \\
\hline 15. SR of JVB & & + & & & & + & + & + & & & & + & & & & & \\
\hline Total observations & 16 & 14 & 2 & 42 & 11 & 13 & 13 & 2 & 2 & 1 & 12 & 12 & 21 & 6 & 6 & 3 & 6 \\
\hline Frecuency of & 18 & 15 & 2 & 46 & 12 & 14 & 14 & 2 & 2 & 1 & 13 & 13 & 23 & 7 & 7 & 3 & 7 \\
\hline
\end{tabular}

appearance (\%)

Notes. 1. MP of the KMW: Management program of the Kisst mountain wetlands; 2. ISRW of KW: Information Sheet on Ramsar Wetlands (RIS) 2006-2008 version (Kisst wetland); 3. KPA Decree: Kisst protected natural area decree, 2011; 4. CDP: City development plan 2015-2018; 5. SCDLCW, A\&D: San Cristobal de Las Casas Wetlands, Chiapas: actors and disputes. Cruz Morales et al, 2010. Journal of Agricultural Geography, no. 44, January-June, pp. 91-104; 6. VJBMP: Valley of Jovel Basin Management Plan; 7. MP of the KMW: Management program of the Maria Eugenia mountain wetlands; 8. ISRW of MEW: Information Sheet on Ramsar Wetlands (RIS). 2006-2008 version Maria Eugenia wetland; 9. MECCVJ: Modeling the effects of climate change in the Valley of Jovel. Santiago Lastra et al, 2016. CaosConciencia10 (1).1-12; 10. (VRF in SCDLC: Vulnerability and risk due to flooding in San Cristóbal de Las Casas, Chiapas. Montoya Gómez et al, 2008. Estudios demográficos y urbanos, vol. 23, núm. 1 (67), 83-122; 11. JVWSW of SCDLC: The Jovel Valley wetlands: source of water for the city of San Cristóbal de Las Casas, its conservation cannot be postponed. Sandra Chediack et al, Technical report, El Colegio de La Frontera Sur, Chiapas, 11 p; 12. DDMW of SCDLC: Diversity of dragonflies (Insecta: Odonata) in the mountain wetlands of San Cristóbal de Las Casas, Chiapas, Mexico (López Díaz: autor's Thesis, Instituto de Ciencias Biológicas, Chiapas); 13. NRIMP in SCDLCB: Natural resources integrated management Plan of the San Cristóbal de las Casas Basin (INIFAP-CENID RASPA, technical report, 73 p; 14. EMPT of the SCDLC: Ecological Management Program of The Territory of the SCDLC city; 15. SR of JVB: Strategy for the Restoration of the Jovel Valley Basin (Pronatura).

Table 4 shows the ecosystem services identified through the revision of local documents, and the equivalent ecosystem services derived from de Groot et al. (2012) used as proxies to estimate the mean values in urban wetlands distributed in SCC. According to the table 4, the ecosystem service category with the highest values is "regulating" with a total value of $\$ 16,415$ per hectare per year, highlighting regulation of water flow and waste treatment/water purification, with a mean value of $\$ 5,606$ per hectare per year and $\$ 3,015$ per hectare per year, 
respectively. Cultural services also have been highly valued in global literature with a mean of $\$ 3,503$ per hectare per year. Provisioning and habitat services are the less valuable services $(\$ 408$ per hectare per year and $\$ 1,287$ per hectare per year, respectively) even though in our local reviewed literature are very important in relation to its representativeness, mainly "collect, store and supply fresh water" provisioning service (Table 3 ).

Table 4. de Groot et al. (2012) ecosystem service equivalents for the ecosystem services found in the local reviewed literature and the corresponding values per unit area (ESV in $2007 \mathrm{USD} \$ / \mathrm{ha} /$ year)

\begin{tabular}{llll}
\hline ES found in the literature & Equivalent ES & No. of used estimated & Mean Value \\
\hline & Provisioning services & 17 & 408 \\
Collect, store and supply fresh water & Fresh water suplly & 17 & 408 \\
Genetic diversity & Genetic resources & - & - \\
& Regulating services & 39 & 16,415 \\
Climate regulation & Climate regulation & 6 & 488 \\
Flood control & Moderation of extrem events & 11 & 2,986 \\
Allow water filtration & Regulation of wáter flows & 5,606 \\
Water purification & Waste treatment/water purification & 3 & 3,015 \\
Soil erosion prevention & Erosión prevention & 2 & 2,607 \\
Retention of nutrients & Nutrient cycling/Maintenance of soil fertility & 2 & 1,713 \\
& Habitat services & 2 & 1,287 \\
Maintaining nursery populations and habitats & Lifecycle maintenance (nursery service) & 2 & 1,287 \\
& Cultural services & 16 & 3,503 \\
Scenic beauty & Aesthetic information & 4 & 1,292 \\
Recreation and tourism & Opportunities for recreation and tourism & 12 & 2,211 \\
Spirituality and religiosity & Spiritual experience & - & - \\
Environmental education and scientific research & Cognitive information & - & - \\
Total & & 74 & 21,613 \\
\hline
\end{tabular}

Note. Modified from de Groot et al. (2012).

\subsection{Changes in Ecosystem Service Values}

Using the estimated change in the size of urban wetland together with the ecosystem service value coefficients reported by de Groot et al. (2012), we found that urban wetland changes in our study area resulted in an average net decline of $\$ 5.63$ million per year in ecosystem services between 2001 and 2018 (Table 5), which represented a significant cost for the local inhabitants. As shown in table 5, the contribution of regulating and cultural services to this decrease is significant, with around $\$ 5$ million per year.

Table 5. Values for each ecosystem service type using de Groot et al. coefficients, and the overall change and rate of change between 2001 and 2018 (ESV in US\$X104)

\begin{tabular}{llllll}
\hline Ecosystem services & Mean Value (Int\$ha/y) & \multicolumn{2}{c}{ Annual flow (Int\$y) } & \multicolumn{2}{c}{ Change 2001-2018 } \\
\cline { 3 - 6 } & & 2001 & 2018 & (Int\$/y) & $\%$ \\
\hline Provisioning Services & 408 & 31.4 & 20.8 & 10.6 & 1.9 \\
Fresh water supply & 408 & 31.4 & 20.8 & 10.6 & 1.9 \\
Genetic resources & - & - & - & - & - \\
Regulating services & 16,415 & $1,264.5$ & 836.3 & 428.2 & 75.9 \\
Climate regulation & 488 & 37.6 & 24.9 & 12.7 & 2.3 \\
Moderation of extreme events & 2,986 & 230 & 152.1 & 77.9 & 13.8 \\
Regulation of water flows & 5,606 & 431.8 & 285.6 & 146.2 & 25.9 \\
Waste treatment/water purification & 3,015 & 232.3 & 153.6 & 78.6 & 13.9 \\
Erosion prevention & 2,607 & 200.8 & 132.8 & 68 & 12.1 \\
Nutrient cycling/maintenance of soil fertility & 1,713 & 132 & 87.3 & 44.7 & 7.9 \\
Habitat services & 1,287 & 99.1 & 65.6 & 33.6 & 6 \\
Lifecycle maintenance (nursery service) & 1,287 & 99.1 & 65.6 & 33.6 & 6 \\
Cultural services & 3,503 & 269.8 & 178.5 & 91.4 & 16.2 \\
Aesthetic information & 1,292 & 99.5 & 65.8 & 33.7 & 6 \\
Opportunities for recreation and tourism & 2,211 & 170.3 & 112.7 & 57.7 & 10.2 \\
Spiritual experience & - & - & - & - & - \\
Cognitive information & - & - & - & - & - \\
Total & 21,613 & $1,664.8$ & $1,101.2$ & 563.8 & \\
\hline
\end{tabular}

Note. Modified from de Groot et al. (2012). 


\subsection{Spatial Variability of Ecosystem Service Values}

Once the annual flow of ESV was determined, a map was created to illustrate the spatial distribution of the ESV losses between 2001 and 2018. Figure 4 shows the total losses. Overall, the highest losses appear to be concentrated in the northwest zone of the study area with values up to 2 million per year, which coincide with the transformation from wetland to urban settlement during the study period. The areas of the lowest losses are mainly located in the south and southeast zone, where protected wetlands are prevalent.

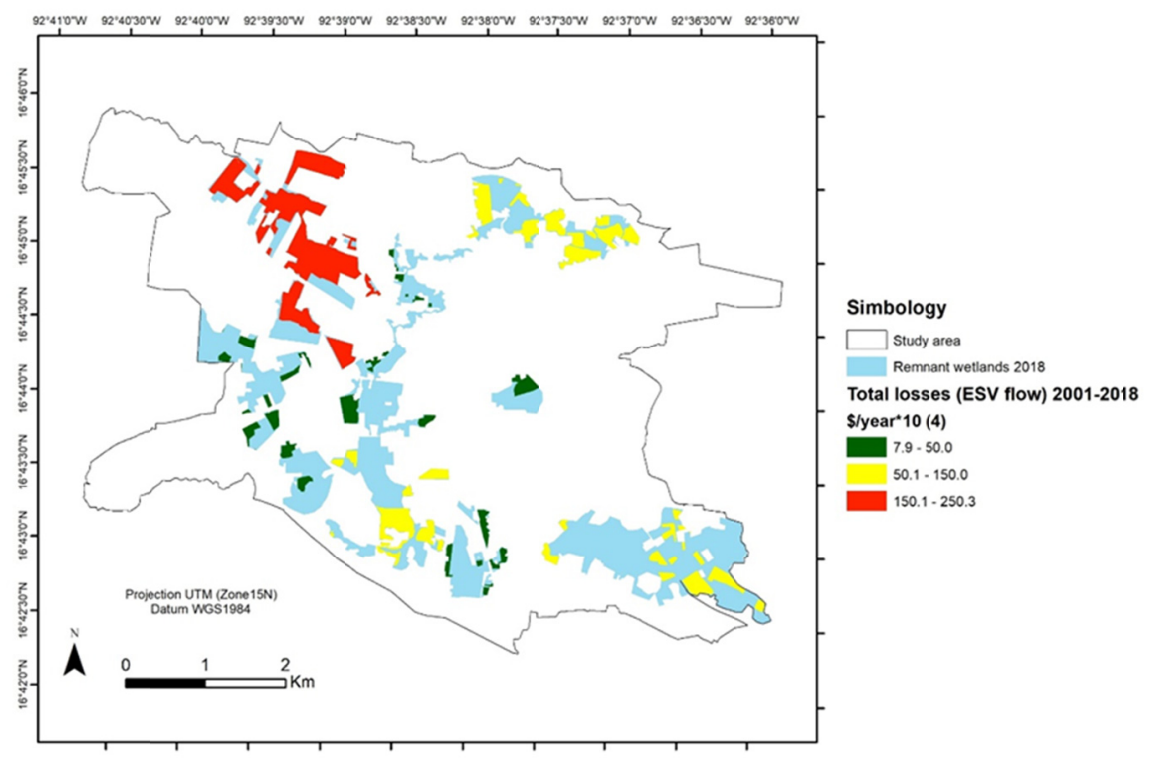

Figure 4. Total losses of ecosystem service value flow between 2001-2018 (ESV X10 ${ }^{4}$ in 2007USD\$/year)

\section{Discussion}

\subsection{Advantages of the Use of Free Satellite Images and GIS}

Thanks to the fast development of technology related to remote sensing and GIS, spatial data availability has increased significantly over the past decade (Hou et al., 2013). While there are debates as to the accuracy of the coverage maps and land use classification derived from satellite images (Alvarez-Martinez et al., 2010), in many cases, remote sensing from satellites, combined with GIS, may be the only economically feasible way to gather regular land cover information in developing countries like Mexico. The generation of maps from high resolution images is expensive, and even detailed maps often have discrepancies at a local level (Maes et al., 2011). Consideration of the spatial complexity in the supply and demand of ecosystem services is fundamental for the understanding of the underlying distribution of benefits and calculation of aggregated values across ecosystems and/or administrative regions. GIS have been used to map the spatial distribution of multiple ecosystem services at local (Lavorel \& Grigulis, 2012), regional (Metzger et al., 2006) and global spatial scales (Ghermandi et al., 2013). Representation of the spatial variability of the provision of ecosystem services in maps is becoming an important tool for planning purposes and conservation decision-making. In this context, this research utilizes both, free satellite images provided by Google Earth platform and SPOT imagery to analyze the distribution of urban wetlands and land uses in San Cristobal and builds on such spatial information to provide a first estimate of the change in the ecosystem service value flows in the region.

\subsection{Ecosystem Service Values}

Our case study of an urban freshwater wetland is currently an underrepresented topic within the literature of Mexican wetland ecosystem services. The majority of these types of studies have focused on the current and historical provisioning services provided by the coastal wetlands of Mexico, which are important habitats for fish and other aquatic resources (Kovacs, 2000; Smardon, 2006). Urban wetlands, especially those within spatially restricted mountainous regions experience very different threats and provide different ecosystem services to those of coastal wetlands in more rural environments (Torres-Lima et al., 2018). 
The few studies, which have assessed the ecosystem or socioeconomic values of urban freshwater wetlands in Mexico, have been done in the wetlands of Xochimilco, in Mexico City (Ibarra et al., 2013; Torres-Lima et al., 2018). These wetlands have a unique cultural importance in Mexico City and provide specific ecosystem services to the surrounding communities. However, the studies of the urban wetlands of Mexico City do demonstrate similarities to those of San Cristobal, of the types of services important to urban areas (especially non-market values such as water filtration and endemic species habitat) (Ibarra et al., 2013), and threats which these urban wetlands face in Mexico (e.g., contamination, urban expansion).

The environmental and economic perceptions of urban wetlands provided as a result of these studies as well as the methods used in our analysis (spatial changes in wetland extents and determination of specific values related to the urban environment), can be used as starting point to evaluate future urban wetlands in this region. The main finding of this study is that can highlight an important aspect of their value (monetary) and demonstrate to urban managers the need to conserve these areas, which may be seen as potential areas of development with little natural value.

Although the values of ecosystem services generated by de Groot (2012) that we have used in our analysis are far from perfect and have methodological challenges (e.g., value heterogeneity or valuation methods), for our context, they represent the most comprehensive and updated set of valuation coefficients available. In fact, the estimations using LULC and established ecosystem service value coefficient, is extremely important in San Cristobal de Las Casas city where ground data collection is expensive and there is scarce data on the historical LULC of urban areas.

\subsection{Influence of Policy in the Degradation of Urban Wetland}

The decrease in urban wetland ESV is largely attributable to the population growth and rapid economic development in the study area that have led to the expansion of construction over urban wetland areas, accelerating the losses of the value of the services provided by these ecosystems. Such conversion of wetland to construction land is in part a result of urban policy design by government (Tovar \& Crispin, 2015).

From the 1990s onwards, Latin American cities have been subject to urban policies that have been characterized by: a) the implementation of new urban planning and renewal legislation; b) the promotion of tourism competitiveness and c) facilitation to the real estate market for residential, commercial, etc., among others (Brites, 2017). Overall, an urban focus which is oriented to install a market logic that favors the real estate speculation of private capital.

Although many cities have formulated urban planning and policy that included guidelines on land development and the future direction of urban growth, rarely have these been implemented. Reasons for this include poor urban governance and poor critical assumptions. Urban population projections underpinning these plans have often been extremely weak and the inability of plans to be adjusted and refined in the light of changing conditions, such as the invasion and settling of unused public space (Cohen, 2006). San Cristobal de Las Casas, selected as our case study, is not the exception to this context, and since the 1970s has experienced rapid urban sprawl without sustainable policy of land use and urban planning (Chediack et al., 2015), causing degradation and loss of urban wetland ecosystems and therefore reducing the provision of ecosystem services to local inhabitants. One of the main environmental and health problems associated with urbanization in the study area is the high contamination of urban wetlands due to the lack of adequate treatment of wastewater (Bencala et al., 2006). In this sense, it is a priority issue to make a sustainable urban planning, which will ensure the provision and maintenance of ecosystem services for local inhabitants over the interests of real estate and commercial speculation.

While there are currently two wetland areas that are under protection (Ramsar and local protection), it is necessary to establish an effective natural protected area system, with adequate management and protection plans, which will ensure the conservation of the scarce surface area of wetlands remaining in the study area (Chediack et al., 2018).

\section{Conclusions}

This study is the first to estimate the change in the ecosystem service values provided by urban wetlands in San Cristobal de Las Casas, Chiapas. Based on the estimated extent of urban wetland cover and the assessment of ESV through international estimates, we determined that the total annual ES values decreased by approximately 5 million (2007 USD) from 2001 to 2018, highlighting the northern zone with the highest concentration of losses, where transformations to urban commercial land are prevalent. Regulating and cultural services were the most valuable ecosystem services. 
The results of this study can provide alternatives and basic information for decision-making processes at urban landscape level, recognizing the value of urban wetlands to human survival and well-being in future land-use and policy formulation in San Cristobal de Las Casas. Otherwise the area of the urban wetland will continue decreasing.

\section{Limitations and Recommendations}

Even though the use of satellite images can be a useful tool for analyze land use/land cover changes, they have some limitations. Onscreen digitizing processes could give us different results depending on the practice and knowledge of the area by the technician. It could lead to a misclassification of bare soils and therefore overestimate the impact of urban sprawl. Regarding this, it is recommended that the image user be the same throughout the digitalization process and have enough knowledge of the area.

There are uncertainties related with the valuation of ecosystem services, especially in our case that we use international data as proxy for estimate wetland values. The main causes of biases in the use of this type of information are related with the heterogeneity of the primary data. This heterogeneity is due data were obtained from different socio-economic contexts and have been estimated through different valuation methodologies, among others. Therefore, it is necessary to include criteria (e.g., take account socio-economic context) or protocols in future primary studies or data sets that help to improve the accuracy of the value coefficients. Although the values estimated have to be taken with caution they can be a useful starting point for the interactions between academic and land decision makers.

In local future studies, it is imperative to obtain data on ecosystem services that more accurately reflect local conditions (Zhao et al., 2004). One approach to achieve this is to incorporate the social perception from ecosystem services by urban dwellers. Socio-cultural valuation approaches appear to be appreciated in understanding the diversity of values emerging from the ecosystem services spectrum and in analyzing how human well-being may be affected by ecological changes (Chan et al., 2012).

\section{Acknowledgments}

We would like to thank Laboratory of Geographic and Statistical Information Analysis (LAIGE-ECOSUR) for providing the SPOT image.

\section{References}

Ahern, J., Cilliers, S., \& Niemelä, J. (2014). The concept of ecosystem services in adaptive urban planning and design: A framework for supporting innovation. Landscape and Urban Planning, 125, 254-259. https://doi.org/10.1016/j.landurbplan.2014.01.020

Álvarez-Martínez, J. M., Stoorvogel, J. J., Suárez-Seoane, S., \& de Luis Calabuig, E. (2010). Uncertainty analysis as a tool for refining land dynamics modelling on changing landscapes: a case study in a Spanish Natural Park. Landscape Ecology, 25, 1385-1404. https://doi.org/10.1007/s10980-010-9492-z

Arriaga, L., Espinoza, J. M., Aguilar, C., Martínez, E., Gómez, L., \& Loa, E. (coords.). (2000). Regiones terrestres prioritarias de México. México, Comisión Nacional para el Conocimiento y Uso de la Biodiversidad (CONABIO).

Atu, J. E., Ayama, O. R., \& Eja, E. I. (2013). Urban sprawl effects on biodiversity in peripheral agricultural Lands in Calabar, Nigeria. A Journal of Environment and Earth Science, 3(7).

Azous, A. L., \& Horner, R. M. (2000). Wetlands and Urbanization: Implications for the Future. Boca Raton, FL, USA: Lewis Publishers.

Barbier, E. B. (2007). Valuing ecosystem services as productive inputs. Economic policy, 22(49), 178-229. https://doi.org/10.1111/j.1468-0327.2007.00174.x

Bencala, K. (2006). A Framework for Developing a Sustainable Watershed Management Plan for San Cristóbal de Las Casas, Chiapas, México (Master's Thesis). Donald Bren School of Environmental Science and Management, U.S.A.

Beninde, J., Veith, M., \& Hochkirch, A. (2015). Biodiversity in cities needs space: a meta-analysis of factors determining intra-urban biodiversity variation. Ecology letters, 18(6), 581-592. https://doi.org/10.1111/ele.12427

Boyer, T., \& Polasky, S. (2004). Valuing urban wetlands: a review of non-market valuation studies. Wetlands, 24(4), 744-755. https://doi.org/10.1672/0277-5212(2004)024[0744:VUWARO]2.0.CO;2

Brites, W. F. (2017). La ciudad en la encrucijada neoliberal. Urbanismo mercado-céntrico y desigualdad 
socio-espacial en América Latina. Urbe Revista Brasileira de Gestão Urbana, 9(3), 573-585. https://doi.org/10.1590/2175-3369.009.003.ao14

Calderon-Cisneros, C., Soto-Pinto, L., \& Estrada-Lugo, E. (2012). Entre la conservación del bosque y el crecimiento de la ciudad: las localidades rurales en el espacio periurbano del Huitepec en San Cristóbal de Las Casas, Chiapas, México. Estudios demográficos y urbanos, 739-787. https://doi.org/10.24201/edu.v27i3.1426

Camacho-Valdez, V., Ruiz-Luna, A., Ghermandi, A., \& Nunes, P. A. (2013). Valuation of ecosystem services provided by coastal wetlands in northwest Mexico. Ocean \& Coastal Management, 78, 1-11. https://doi.org/10.1016/j.ocecoaman.2013.02.017

Chaikumbung, M., Doucouliagos, H., \& Scarborough, H. (2016). The economic value of wetlands in developing countries: A meta-regression analysis. Ecological Economics, 124, 164-174. https://doi.org/10.1016/j.ecolecon.2016.01.022

Chan, K. M., Satterfield, T., \& Goldstein, J. (2012). Rethinking ecosystem services to better address and navigate cultural values. Ecological economics, 74, 8-18. https://doi.org/10.1016/j.ecolecon.2011.11.011

Chediack, S. E., Soria-Barreto, M., González-Figueroa, G., Mondragón-Ríos, R., Valencia-Barrera, E., Ramírez-Marcial, N. et al. (2015). Los humedales del valle de Jovel, la fuente de agua para la ciudad de San Cristóbal de Las Casas: su conservación es impostergable. Informe técnico. El Colegio de la Frontera Sur, San Cristóbal de las Casas, Chiapas, México.

Chediack, S. E., Ramírez-Marcial, N., Martínez-Icó, M., \& Castañeda-Ocaña, H. E. (2018). Macrófitos de los humedales de montaña de San Cristóbal de Las Casas, Chiapas, México. Revista Mexicana de Biodiversidad, 89(3), 757-768. https://doi.org/10.22201/ib.20078706e.2018.3.2420

Cohen, B. (2006). Urbanization in developing countries: Current trends, future projections, and key challenges for sustainability. Technology in society, 28(1-2), 63-80. https://doi.org/10.1016/j.techsoc.2005.10.005

Colding, J. (2011). The role of ecosystem services in contemporary urban planning. Urban Ecology: Patterns, Processes, and Applications, 228-237.

Costanza, R., d'Arge, R., De Groot, R., Farber, S., Grasso, M., Hannon, B., ... Raskin, R. G. (1997). The value of the world's ecosystem services and natural capital. Nature, 387(6630), 253. https://doi.org/10.1038/387253a0

Chuai, X., Huang, X., Wu, C., Li, J., Lu, Q., Qi, X., ... Lu, J. (2016). Land use and ecosystems services value changes and ecological land management in coastal Jiangsu, China. Habitat International, 57, 164-174. https://doi.org/10.1016/j.habitatint.2016.07.004

Cruz Morales, J., \& Hernández Pérez, F. (2010). Los humedales de San Cristóbal de Las Casas, Chiapas: actores y disputas. Revista de Geografia Agrícola, 44.

De Groot, R., Brander, L., Van Der Ploeg, S., Costanza, R., Bernard, F., Braat, L., ... Hussain, S. (2012). Global estimates of the value of ecosystems and their services in monetary units. Ecosystem Services, 1(1), 50-61. https://doi.org/10.1016/j.ecoser.2012.07.005

De Jong, B. H., Cairns, M. A., Haggerty, P. K., Ramírez-Marcial, N., Ochoa-Gaona, S., Mendoza-Vega, J., \& MARCH-MIFSUT, I. G. N. A. C. I. O. (1999). Land-use change and carbon flux between 1970s and 1990s in central highlands of Chiapas, Mexico. Environmental Management, 23(3), 373-385.

Derkzen, M. L., Teeffelen, A. J., \& Verburg, P. H. (2015). Quantifying urban ecosystem services based on high-resolution data of urban green space: an assessment for Rotterdam, the Netherlands. Journal of Applied Ecology, 52(4), 1020-1032. https://doi.org/10.1111/1365-2664.12469

Elmqvist, T., Folke, C., Nyström, M., Peterson, G., Bengtsson, J., Walker, B., \& Norberg, J. (2003). Response diversity, ecosystem change, and resilience. Frontiers in Ecology and the Environment, 1(9), 488-494. https://doi.org/10.1890/1540-9295(2003)001[0488:RDECAR]2.0.CO;2

Epstein, J., Payne, K., \& Kramer, E. (2002). Techniques for mapping suburban sprawl. Photogrammetric Engineering and Remote Sensing, 68(9), 913-918.

Figueroa-Jáuregui, M. L., Ibáñez-Castillo, L. A., Arteaga-Ramirez, R., Arellano-Monterrosas, J. L., \& Vazquez-Pena, M., 2011. Land use change in San Cristóbal de las Casas watershed, México. Agrociencia (Montecillo), 45(5), 531-544. 
Ghermandi, A., Ding, H., \& Nunes, P. A. L. D. (2013). The social dimension of biodiversity policy in the European Union: valuing the benefits to vulnerable communities. Environmental Science \& Policy, 33, 196-208. https://doi.org/10.1016/j.envsci.2013.06.004

Glaeser, E. L., \& Kahn, M. E. (2004). Sprawl and Urban Growth. Handbook of Regional and Urban Economics (vol. IV., pp. 2481-2527). Elsevier, Amsterdam. https://doi.org/10.1016/S1574-0080(04)80013-0

Gómez, G. M., Ruiz, J. F. H., Santiago, M. Á. C., Bonifaz, D. M. D., \& Pérez, A. V. (2008). Vulnerabilidad y riesgo por inundación en San Cristóbal de Las Casas, Chiapas. Estudios demográficos y urbanos, 83-122. https://doi.org/10.24201/edu.v23i1.1304

Gómez-Baggethun, E., \& Barton, D. N. (2013). Classifying and valuing ecosystem services for urban planning. Ecological Economics, 86, 235-245. https://doi.org/10.1016/j.ecolecon.2012.08.019

Green, T. L., Kronenberg, J., Andersson, E., Elmqvist, T., \& Gomez-Baggethun, E. (2016). Insurance value of green infrastructure in and around cities. Ecosystems, 19(6), 1051-1063. https://doi.org/10.1007/s10021-016-9986-x

Grimm, N. B., Faeth, S. H., Golubiewski, N. E., Redman, C. L., Wu, J., Bai, X., \& Briggs, J. M. (2008). Global change and the ecology of cities. Science, 319(5864), 756-760. https://doi.org/10.1126/science.1150195

Guo, Z., Shao, X., Xu, Y., Miyazaki, H., Ohira, W., \& Shibasaki, R. (2016). Identification of village building via Google Earth images and supervised machine learning methods. Remote Sensing, 8(4), 271. https://doi.org/10.3390/rs8040271

Haack, B. N., \& Rafter, A. (2006). Urban growth analysis and modeling in the Kathmandu Valley, Nepal. Habitat International, 30(4), 1056-1065. https://doi.org/10.1016/j.habitatint.2005.12.001

Haase, D., Larondelle, N., Andersson, E., Artmann, M., Borgström, S., Breuste, J., ... Kabisch, N. (2014). A quantitative review of urban ecosystem service assessments: concepts, models, and implementation. Ambio, 43(4), 413-433. https://doi.org/10.1007/s13280-014-0504-0

Hou, Y., Burkhard, B., \& Müller, F. (2013). Uncertainties in landscape analysis and ecosystem service assessment. Journal of Environmental Management, 127(supplement), 117-131. https://doi.org/10.1016/j.jenvman.2012.12.002

Ibarra, A. A., Zambrano, L., Valiente, E. L., \& Ramos-Bueno, A. (2013). Enhancing the potential value of environmental services in urban wetlands: An agro-ecosystem approach. Cities, 31, 438-443. https://doi.org/10.1016/j.cities.2012.08.002

Instituto Nacional de Estadística y Geografía (INEGI). (2010a). Censo de población y vivienda, 156.

Instituto Nacional de Estadística y Geografía (INEGI). (2010b). Perspectiva Estadística Chiapas, 95.

Instituto Nacional de Estadística y Geografía (INEGI). (2014). Polígonos de localidades urbanas geoestadísticas, 80.

Jiménez, F. E. J., \& Salinas, D. O. (2007). Ficha Informativa de los Humedales de Ramsar (FIR)-Versión 20062008. Comisión Nacional de Áreas Naturales Protegidas.

Jujnovsky, J., González-Martínez, T. M., Cantoral-Uriza, E. A., \& Almeida-Leñero, L. (2012). Assessment of water supply as an ecosystem service in a rural-urban watershed in southwestern Mexico City. Environmental Management, 49(3), 690-702. https://doi.org/10.1007/s00267-011-9804-3

Kovacs, J. M. (2000). Perceptions of environmental change in a tropical coastal wetland. Land Degradation \& Development, $11(3)$, 209-220. https://doi.org/10.1002/1099-145X(200005/06)11:3<209::AID-LDR378>3.0.CO;2-Y

Kremer, P., Hamstead, Z. A., \& McPhearson, T. (2016). The value of urban ecosystem services in New York City: A spatially explicit multicriteria analysis of landscape scale valuation scenarios. Environmental Science \& Policy, 62, 57-68. https://doi.org/10.1016/j.envsci.2016.04.012

Kreuter, U. P., Harris, H. G., Matlock, M. D., \& Lacey, R. E. (2001). Change in ecosystem service values in the San Antonio area, Texas. Ecological Economics, 39(3), 333-346. https://doi.org/10.1016/S0921-8009(01)00250-6

Kumar, M., \& Kumar, P. (2008). Valuation of the ecosystem services: a psycho-cultural perspective. Ecological Economics, 64(4), 808-819. https://doi.org/10.1016/j.ecolecon.2007.05.008

Lavorel, S., \& Grigulis, K. (2012). How fundamental plant functional trait relationships scale-up to trade-offs 
and synergies in ecosystem services. Journal of Ecology, 100, 128-140. https://doi.org/10.1111/j.1365-2745.2011.01914.x

Li, J., Wang, W., Hu, G., \& Wei, Z. (2010). Changes in ecosystem service values in Zoige Plateau, China. Agriculture, Ecosystems \& Environment, 139(4), 766-770. https://doi.org/10.1016/j.agee.2010.10.019

Libertun, N., \& Guerrero, R. (2017). Cuánto cuesta la densificación? La relación entre la densidad y el costo de proveer servicios urbanos básicos en Brasil, Chile, Ecuador y México. EURE (Santiago), 43(130), $235-267$. https://doi.org/10.4067/s0250-71612017000300235

Luederitz, C., Brink, E., Gralla, F., Hermelingmeier, V., Meyer, M., Niven, L., ... \& Abson, D. J. (2015). A review of urban ecosystem services: six key challenges for future research. Ecosystem Services, 14, 98-112. https://doi.org/10.1016/j.ecoser.2015.05.001

Maes, J., Egoh, B., Willemen, L., Liquete, C., Vihervaara, P.,..\& Schägner, J. P. (2012). Mapping ecosystem services for policy support and decision making in the European Union. Ecosystem Services, 1, 31-39. https://doi.org/10.1016/j.ecoser.2012.06.004

McDonald, R., \& Marcotullio, P. (2011). Global effects of urbanization on ecosystem services. Urban ecology (pp. 193-205). Oxford: Oxford University https://doi.org/10.1093/acprof:oso/9780199563562.003.0024

McPhearson, T., Kremer, P., \& Hamstead, Z. A. (2013). Mapping ecosystem services in New York City: Applying a social-ecological approach in urban vacant land. Ecosystem Services, 5, 11-26. https://doi.org/10.1016/j.ecoser.2013.06.005

Merlín-Uribe, Y., Contreras-Hernández, A., Astier-Calderón, M., Jensen, O. P., Zaragoza, R., \& Zambrano, L. (2013). Urban expansion into a protected natural area in Mexico City: alternative management scenarios. Journal of Environmental Planning and Management, 56(3), 398-411. https://doi.org/10.1080/09640568.2012.683686

Mendoza-González, G., Martínez, M. L., Lithgow, D., Pérez-Maqueo, O., \& Simonin, P. (2012). Land use change and its effects on the value of ecosystem services along the coast of the Gulf of Mexico. Ecological Economics, 82, 23-32. https://doi.org/10.1016/j.ecolecon.2012.07.018

Merino, P., 2013. Diversidad de aves asociadas a los humedales de montaña en San Cristóbal de las Casas, Chiapas, México. Bachelor Thesis, Facultad de Ciencias Biológicas, UNICACH. 71.

Metzger, M. J., Rounsevell, M. D. A., Acosta-Michlik, L., Leemans, R., \& Schroter, D. (2006). The vulnerability of ecosystem services to land use change. Agriculture, Ecosystems \& Environment, 114, 69-85. https://doi.org/10.1016/j.agee.2005.11.025

Millennium Ecosystem Assessment (MEA). (2005). Ecosystems and Human WellBeing: Synthesis. Island Press.

Mitsch, W. J., \& Gosselink, J. G. (2000). The value of wetlands: importance of scale and landscape setting. Ecological Economics, 35(1), 25-33. https://doi.org/10.1016/S0921-8009(00)00165-8

Montgomery, M. R. (2008). The urban transformation of the developing world. Science, 319(5864), $761-764$. https://doi.org/10.1126/science.1153012

Mosammam, H. M., Nia, J. T., Khani, H., Teymouri, A., \& Kazemi, M. (2017). Monitoring land use change and measuring urban sprawl based on its spatial forms: The case of Qom city. The Egyptian Journal of Remote Sensing and Space Science, 20(1), 103-116. https://doi.org/10.1016/j.ejrs.2016.08.002

Perez-Verdin, G., Sanjurjo-Rivera, E., Galicia, L., Hernandez-Diaz, J. C., Hernandez-Trejo, V., \& Marquez-Linares, M. A. (2016). Economic valuation of ecosystem services in Mexico: Current status and trends. Ecosystem Services, 21, 6-19. https://doi.org/10.1016/j.ecoser.2016.07.003

Poelmans, L., \& Van Rompaey, A. (2009). Detecting and modelling spatial patterns of urban sprawl in highly fragmented areas: A case study in the Flanders-Brussels region. Landscape and Urban Planning, 93(1), 1019. https://doi.org/10.1016/j.landurbplan.2009.05.018

Rojas-Garcia, J., Alba-Lopez, M.P. (2011). Los Humedales de San Cristóbal de las Casas, Chiapas, Mexico. Pro Natura Sur.

Smardon, R. C. (2006). Heritage values and functions of wetlands in Southern Mexico. Landscape and Urban Planning, 74(3-4), 296-312. https://doi.org/10.1016/j.landurbplan.2004.09.009

Su, S., Xiao, R., Jiang, Z., \& Zhang, Y. (2012). Characterizing landscape pattern and ecosystem service value 
changes for urbanization impacts at an eco-regional scale. Applied Geography, 34, 295-305. https://doi.org/10.1016/j.apgeog.2011.12.001

TEEB. (2011). TEEB manual for cities: ecosystem services in urban management. The Economics of Ecosystem Services and Biodiversity.

Tong, C., Feagin, R. A., Lu, J., Zhang, X., Zhu, X., Wang, W., \& He, W. (2007). Ecosystem service values and restoration in the urban Sanyang wetland of Wenzhou, China. Ecological Engineering, 29(3), 249-258. https://doi.org/10.1016/j.ecoleng.2006.03.002

Torres-Lima, P., Conway-Gómez, K., \& Buentello-Sánchez, R. (2018). Socio-Environmental Perception of an Urban Wetland and Sustainability Scenarios: A Case Study in Mexico City. Wetlands, 38(1), 169-181. https://doi.org/10.1007/s13157-017-0967-4

Tovar, J. R. G., \& Crispín, Á. S. (2015). Estructura territorial del turismo en San Cristóbal de las Casas, Chiapas, México. Cuadernos de Turismo, 35, 185-209. https://doi.org/10.6018/turismo.35.221571

Turner, R. K., Georgiou, S., \& Fisher, B. (2008). Valuing ecosystem services: The case of multi-functional wetlands. London.

United Nations (UN), Department of Economic and Social Affairs, Population Division. (2016). The World's Cities in 2016-Data Booklet (ST/ESA/ SER.A/392).

Vásquez-Moreno, L., \& Córdova, A. (2013). A conceptual framework to assess urban agriculture's potential contributions to urban sustainability: An application to San Cristobal de Las Casas, Mexico. International Journal of Urban Sustainable Development, 5(2), 200-224. https://doi.org/10.1080/19463138.2013.780174

Velázquez-Velázquez, E., \& Schmitter-Soto, J. J. (2004). Conservation status of the San Christóbal pupfish Profundulus hildebrandi Miller (Teleostei: Profundulidae) in the face of urban growth in Chiapas, Mexico. Aquatic Conservation: Marine and Freshwater Ecosystems, 14(2), 201-209. https://doi.org/10.1002/aqc.605

Velázquez-Velázquez, E., Schmitter-Soto, J., \& Domínguez-Cisneros, S. (2009). Threatened fishes of the world: Profundulus hildebrandi Miller, 1950 (Profundulidae). Environmental Biology of Fishes, 84(4), 345-346. https://doi.org/10.1007/s10641-008-9425-8

Wilson, E. H., Hurd, J. D., Civco, D. L., Prisloe, M. P., \& Arnold, C. (2003). Development of a geospatial model to quantify, describe and map urban growth. Remote Sensing of Environment, 86(3), 275-285. https://doi.org/10.1016/S0034-4257(03)00074-9

Whitford, V., Ennos, A. R., \& Handley, J. F. (2001). "City form and natural process"-indicators for the ecological performance of urban areas and their application to Merseyside, UK. Landscape and Urban Planning, 57(2), 91-103. https://doi.org/10.1016/S0169-2046(01)00192-X

Yirsaw, E., Wu, W., Temesgen, H., \& Bekele, B. (2016). Effect of temporal land use/land cover changes on ecosystem services value in coastal area of China: The case of Su-Xi-Chang region. Applied Ecology and Environmental Research, 14(3), 409-422. https://doi.org/10.15666/aeer/1403_409422

Zhao, B., Kreuter, U., Li, B., Ma, Z., Chen, J., \& Nakagoshi, N. (2004). An ecosystem service value assessment of land-use change on Chongming Island, China. Land Use Policy, 21(2), 139-148. https://doi.org/10.1016/j.landusepol.2003.10.003

\section{Copyrights}

Copyright for this article is retained by the authors, with first publication rights granted to the journal.

This is an open-access article distributed under the terms and conditions of the Creative Commons Attribution license (http://creativecommons.org/licenses/by/4.0). 